\title{
El amargo exilio de Victoriano Huerta y sus seguidores en España: 1914-1920
}

Victoriano Huerta's bitter exile and his followers in Spain: 1914-1920

\section{Mario Ramírez Rancaño}

Resumen

Palabras clave

Abstract

Keywords
Instituto de Investigaciones Sociales, Universidad Nacional Autónoma de México, Ciudad de México, México

Correo electrónico: marara2005@yahoo.com.mx

Es doctor en Sociología por la Escuela de Altos Estudios en Ciencias Sociales (Paris, Francia), e investigador titular en el Instituto de Investigaciones Sociales de la Universidad Nacional Autónoma de México. En 2014 publicó El asesinato de Álvaro Obregón: la conspiración y la madre Conchita.

A la renuncia de Victoriano Huerta a la Presidencia de México, gran parte del personal político y militar se refugió en Estados Unidos, Cuba, y otros países. Huerta se exilió en España, al igual que otros miembros de su gabinete. Dado que España fue uno de los países cuyo gobierno reconoció a Huerta, los recién llegados supusieron que recibirían un trato especial, pero no fue así. Casi al mismo tiempo estalló la guerra mundial, lo cual agravó la situación de los exiliados. Al final, casi todos regresaron a América, en especial a los Estados Unidos.

Exiliados, revolución mexicana, huertismo, ejército federal, apoyo alemán

Once Victoriano Huerta resigned as President of Mexico, a large portion of politicians and military personnel took refuge in the United States, Cuba, and other countries. Huerta was exiled in Spain, as did other members of his cabinet. Since Spain was one of the countries whose government recognized Huerta, the newcomers assumed that they would receive special treatment, but that was not the case. Almost simultaneously,the Grat War began, which made the exiles' situation even worse. Finaly, almost every one of them returned to the Americas, specially to the United States.

Exiles, Mexican Revolution, huertism, federal army, German support
Recibido/Received

Aprobado/Approved
13 de junio de 2017

12 de abril de 2018 


\title{
El amargo exilio de Victoriano Huerta y sus seguidores en España: 1914-1920
}

\author{
Mario Ramírez Rancaño
}

Como es sabido, el 15 de julio de 1914, Victoriano Huerta renunció a la Presidencia de la República, y abandonó el país junto con Aurelio Blanquet, su ex secretario de Guerra y Marina. Lo que resultó insólito fue que se dirigieran a España, un país con el cual los lazos o vínculos eran bastante ríspidos. Cuatro razones explicativas surgen a la vista: la primera, quedar lejos de Venustiano Carranza, y por ende, evitar que les aplicaran la ley de enero de 1862 que los condenaba a la pena de muerte. ${ }^{1}$ Segunda: dirigirse a los Estados Unidos significaba un grave riesgo ya que podrían resultar atrapados y entregados a Carranza o a Francisco Villa, quienes los tratarían con suma crueldad. Tercera: España fue uno de los países que primero reconocieron su gobierno, y Huerta supuso que ahí su exilio podría resultar halagüeño. La razón: los vínculos comerciales con el citado país siempre habían sido muy estrechos. En 1913, México tenía ahí 28 consulados, ocupando el tercer lugar al nivel mundial. Cuarta: algunos de los cónsules habían sido designados por la administración huertista, y el resto, ratificados. Por tales razones, Huerta y sus correligionarios esperaban una recepción cálida y amigable.

En realidad, apenas pisaron suelo ibérico, todo se derrumbó. A lo expuesto, habría que agregar que en forma inesperada, estalló una ruptura previsiblemente violenta entre Huerta y Blanquet, cuyas razones no son conocidas, y todo indica que jamás lo serán. Manuel Mondragón, ex secretario de Guerra y Marina, que tenía varios meses de vivir en Santander, ignoró su llegada. José Refugio Velasco, el tercer ex secretario de Guerra y Marina, que llegó días más

${ }^{1}$ El Constitucionalista, 4 de diciembre de 1913. 
tarde, no tuvo contacto con ellos. Para arruinar el cuadro, un viejo aliado, Rodolfo Reyes, que dio fundamento al Pacto de la Embajada, volcó sus simpatías por Félix Díaz exiliado en los Estados Unidos. ${ }^{2}$ Para mayor desgracia, estalló la primera guerra mundial, y España fijó sus miras en los países vecinos, y en la suerte de sus conciudadanos que retornaron de Francia, Italia, y otros países. De ahí que el exilio de Huerta y sus seguidores, cuyo número se calcula en un centenar, haya sido dramático y desastroso. Tan desastroso, que a los pocos meses, casi todos abandonaron la "madre patria”, y se dirigieron a los Estados Unidos y Cuba.

No obstante su relevancia, el tema apenas ha sido tocado por un reducido grupos de analistas. Un primer grupo ha abordado el tema en forma un tanto global. Nos referimos a Sax en su libro Los mexicanos en el destierro, González Navarro, en el tercer volumen de Los extranjeros en México y los mexicanos en el extranjero 1821-1970, Ramírez Rancaño, en La reacción mexicana y su exilio durante la revolución de 1910, Garciadiego y Kouri, en Revolución y exilio en la historia de México: del amor del historiador a su patria adoptiva. Homenaje a Friedrick Katz. ${ }^{3}$ Un segundo grupo analiza el tema en forma más directa el exilio en España destacando Rosenzweig, "Los diplomáticos mexicanos durante la revolución: entre el desempleo y el exilio”, y Perea, La rueda del tiempo. ${ }^{4}$ El tercer grupo contempla textos más puntuales destacando Garciadiego, “Alfonso Reyes. Cosmopolitismo diplomático y universalismo literario”, Portal, “El exilio madrileño de Martín Luis Guzmán”, Jiménez Aguirre, “Amado Nervo. Una crónica de tres tiempos”, Castillo, "Estudio preliminar”, y por otros académicos en sendos artículos de investigación. ${ }^{5}$ En los cuatro primeros textos se rastrea el exilio del personal político huertista y porfirista en los Estados Unidos, Cuba, y en menor medida en España y Francia. En particular, sobre el exilio de los mexicanos en España, la literatura es creciente y es reseñada en parte en los textos señalados.

\footnotetext{
2 Reyes (1930, p. 34-37).

3 Sax (1916); González Navarro (1994); Ramírez Rancaño (2002); Garciadiego y Kouri (2010).

4 Rosenzweig (2012); Perea (1996).

5 Garciadiego (1998); Portal (1993); Jiménez Aguirre (1998); Castillo (1980).
} 
¿España: santuario adverso de huertistas?

Por siglos, fue común que la "madre patria" enviara miles y miles de súbditos a sus ex colonias ubicadas en el continente americano, y otros lares, pero no a la inversa. En forma sorpresiva, durante la revolución mexicana, el fenómeno se revirtió, y España, ubicada a más de diez mil kilómetros de distancia, se convirtió en forma inesperada en el tercer santuario de huertistas después de los Estados Unidos y Cuba. Para cruzar el océano Atlántico, los fugitivos utilizaron barcos de distintas compañías, entre ellas de la Compañía Trasatlántica Española y barcos franceses. Un buen número de barcos llegaban a la península por el puerto de Santander, en el mar Cantábrico, y otros por el de Cádiz. De ambos, el primero fue el preferido. De Santander, los viajeros se desplazaron a San Sebastián, a Madrid, Barcelona y otras ciudades. Pero el mexicano que arribaba a las costas españolas, se topaba con un mundo extraño y desconocido. Ningún sobresalto o interés causaba. Peor aún, los recién llegados cargaban con el estigma de haber sido partícipes del asesinato del presidente de la República, Francisco I. Madero, y del vicepresidente, José María Pino Suárez.

Pero hubo otros factores que conspiraron en su contra. El principal, el estallido de la primera guerra mundial, lo cual ha dado lugar a dos versiones encontradas sobre sus efectos en España. Uno que dicta prosperidad, y el otro, miseria. En realidad, aprovechando su neutralidad, España se convirtió en abastecedora de cuantos productos agrícolas e industriales requirieron los países envueltos en el conflicto. Fue una suerte de aliento para que su economía se reactivara. ${ }^{6}$ Ciertamente que hubo problemas con los excedentes de población en edad laboral, pero fueron resueltos utilizando un viejo expediente: su transferencia hacia la América. Por otro lado, se registró la salida de muchos extranjeros residentes en España, como fue el caso de los franceses, alemanes, ingleses, y otros, quienes se marcharon hacia sus países de origen para empuñar las armas. De ahí que las cosas se nivelaran. En este contexto, tanto el gobierno español como la opinión pública fijaron sus miras en Francia, Inglaterra, Alemania, Italia, atrapados por los vaivenes de la guerra, y las noticias provenientes

\footnotetext{
${ }^{6}$ Caspistegui (2014, p. 17, 161-163, 169).
} 
de México y del resto de América Latina, escasas por cierto, poco o nada les importaron. No aparecen reflejadas en la prensa, y muy poco en los archivos.

\section{Un alud de quejas}

Desde el ascenso de Huerta al poder en febrero de 1913, y aún antes, hubo una gran cantidad de protestas de las autoridades españolas por la suerte que corrían sus súbditos en México. A finales del citado año, el Marqués de Lema, ministro de Asuntos Exteriores, le hizo un extrañamiento a Francisco A. de Icaza, ministro Plenipotenciario de México en España, por la suerte de sus conciudadanos.? Pero las cosas subieron de tono, y el 3 de febrero de 1914, el diario La Atalaya afirmaba que en cada vapor que arribaba a las costas españolas, los viajeros narraban historias de martirios y humillaciones sufridas por sus compatriotas en la anárquica república mexicana, y luego vino una afirmación descabellada: que "el número de españoles asesinados en las haciendas mexicanas se [elevaba] a millones". Para concluir, en plan retador, afirmaba que no podía consentirse, que en pleno siglo xx, se robara a los españoles el fruto del trabajo de toda su vida, así como se les desvalijara, se les expoliara y se les asesinara. ${ }^{8}$ La versión era alarmista y falsa. Nunca hubo millones de españoles en México.

Asimismo, hubo un incidente sobre el cual existe cierta confusión, ya que señalaba a Huerta como culpable de ofender a los españoles. Sin precisar la fecha, se afirmó que durante un banquete celebrado en el Palacio Presidencial de México, con la asistencia del cuerpo diplomático, del comandante del crucero español Carlos V, del representante de España, y varios oficiales, a la hora del brindis, "el ebrio presidente Huerta, y centelleándole sus ojos sanguinarios, se permitió decir: Yo no digo que todos los españoles sean unos pícaros, pero sí digo que todos los pícaros son de España”. Supuestamente, al escuchar esto, los representantes de Francia y Alemania se levantaron y se retiraron. ${ }^{9}$ Para el secretario de la Legación de México en Santander, Vicente Veloz González, las tan comentadas palabras atribuidas a Huerta carecían de la significación. Por

\footnotetext{
7 SRE-AHD, leg. 343, f. 13.

${ }^{8}$ La Atalaya, 3 de febrero de 1914.

9 La Atalaya, 3 de febrero de 1914.
} 
lo demás, no se trató de un acto oficial, sino de una fiesta un tanto familiar que tuvo lugar en uno de los salones del Jockey Club. Al evento acudieron varios españoles, y a la hora de los postres, salieron a relucir los vejámenes sufridos por los españoles en Chihuahua. Dado el carácter íntimo y familiar del banquete, Huerta dio unos golpecitos en la espalda de un español, y exclamó: “iA los españoles no hay quien los mate! iBuenos pícaros están ustedes!”. El tono fue de franca camaradería y jamás de agravio. Ninguno de los asistentes dio a las palabras de Huerta, un contenido agraviante, ni se retiró en señal de protesta. ${ }^{10}$

\section{La renuncia de Victoriano Huerta y Aurelio Blanquet}

El miércoles 15 de julio de 1914, y tras 17 meses de estancia en el poder, Victoriano Huerta presentó su renuncia a la presidencia de la República, al igual que todo su gabinete. En forma lacónica, El País reportaba que a las tres de la tarde, acompañado de varios de sus ex ministros y algunos ayudantes, Huerta salió de la capital de la República rumbo a la estación del Ferrocarril Interoceánico de los Reyes, ubicada a unos 18 kilómetros. ${ }^{11}$ Su salida fue advertida por algunos vecinos de las calles cercanas a la estación ferroviaria de San Lázaro. Al observar el paso de la caravana de automóviles, desde los balcones de sus casas, la gente agitó sus pañuelos en señal de despedida. A llegar a la estación de Los Reyes, los fugitivos dejaron los automóviles y abordaron el convoy presidencial. De la estación Los Reyes, el convoy se dirigió al cruce de las líneas del Ferrocarril Mexicano y del Interoceánico, ubicado entre Irolo y Apizaco. Aquí cambiaron de tren, y a la una y media de la mañana, reanudaron su marcha rumbo a Puerto México, a donde llegaron el 17 al mediodía.

$\mathrm{Al}$ esparcirse los rumores de su renuncia, se especuló que probablemente Huerta abordaría el vapor Alfonso XIII o bien el Espagne, anclados en Puerto México. Lorenzo Meyer afirma que su renuncia, y la incertidumbre sobre cuál barco abordaría, creó una serie de inconvenientes para España. El ministro español en México, Bernardo de Cólogan y Cólogan, le indicó al comandante del Carlos $v$ anclado en Veracruz, que sí Huerta aparecía en ese puerto, no se

${ }^{10}$ La Atalaya, 4 de febrero de 1914 .

${ }^{11}$ El País, 16 de julio de 1914. 
le rindieran honores como a todo ex jefe de Estado, ni se le aceptara a él, o a su cómplice, Aurelio Blanquet, en algún barco de la Compañía Trasatlántica Española. ${ }^{12}$ Por suerte, los fugitivos tenían otros planes. Sus colaboradores habían hecho los preparativos para abordar el crucero alemán Dresden. Según el New York Times, el 17 de julio, el capitán Kohler, junto con los oficiales a su mando, recibieron al ex dictador mexicano a bordo del crucero Dresden, anclado en Puerto México. ${ }^{13} \mathrm{El} 20$ de julio zarparon, y cuatro días más tarde atracaron en Kingston, Jamaica. Días después, Huerta, Blanquet y sus familias, abordaran el Patia, un vapor americano de la United Fruit Company, para trasladarse a Inglaterra. Según George J. Rausch Jr., el 16 de agosto llegaron a Bristol. ${ }^{14}$ Huerta y su familia tomaron un tren para visitar Londres, hospedándose en un oscuro hotel. Recorrieron la citada ciudad, y el 24 de agosto regresaron a Bristol.

Al sospechar que Huerta pretendía radicar en España, Bernardo de Cólogan y Cólogan le sugirió al Ministerio de Asuntos Exteriores en Madrid, que en caso de que fuera así, ninguna institución española lo agasajara, y la prensa se abstuviera de elogiarlo ya que causaría una pésima impresión entre los españoles residentes en México. A continuación vino la puntilla: el ministro, marqués de Lema, comunicó al gobernador de Guipúzcoa, que sí acaso Huerta atracaba en algún puerto de esa comunidad, se le insinuara "discretamente que el Gobierno de S.M. vería con gusto [que] no estableciese su residencia en España”. Y sí Huerta insistía, existía la posibilidad de extraditarlo si lo pedía el nuevo gobierno constitucionalista. ${ }^{15}$ Oscar Flores reafirma esta directriz. A su juicio, con el objeto de no tener problemas con el gobierno constitucionalista, las autoridades españolas le hicieron saber a Huerta que, en aras de las nuevas relaciones con México, lo más prudente era que fijara su residencia fuera de la península. ${ }^{16} \mathrm{En}$

${ }^{12}$ Meyer (2001, p. 138).

13 New York Times, 18 de julio de 1914, citado por Tuchman (2010, p. 82).

14 Rausch (1961, p. 133, 134), y Meyer (1983, p. 235, 236).

${ }^{15}$ Archivo del Ministerio de Asuntos Exteriores (en adelante AMAE), Madrid y Alcalá de Henares, Madrid, Lema al gobernador de Guipúzcoa, 1-2558, TC, Madrid, 25 de agosto de 1914, citado por Flores (2001, p. 314).

${ }^{16}$ AMAE, Madrid, Riaño a Lema, 1-2560, d-247, Washington, 12 de mayo de 1915, citado por Flores (2001, p. 453). 
Tabla 1

Posible derrotero de Huerta

\begin{tabular}{|c|c|}
\hline CONCEPTO & FECHA \\
\hline Salida de la Ciudad de México & 15 de julio de 1914 \\
\hline Llegada a Puerto México & 17 de julio de 1914 \\
\hline Salida hacia Kingston, Jamaica, en el vapor Dresden & 20 de julio de 1914 \\
\hline Llegada a Kingston, Jamaica & 24 de julio de 1914 \\
\hline Llegada de Huerta a Bristol, Inglaterra en el Patia & 16 de agosto de 1914 \\
\hline Huerta y su familia de visita en Londres & 17 de agosto de 1914 \\
\hline $\begin{array}{l}\text { Llegada del vapor Buenos Aires al puerto de Cádiz, } \\
\text { en el cual llegaba su hijo Víctor }\end{array}$ & 18 de agosto de 1914 \\
\hline Retorno de Huerta a Bristol & 24 de agosto de 1914 \\
\hline Llegada de Huerta a Santander & 27 de agosto de 1914 \\
\hline Huerta y Blanquet hacia Cádiz & 29 de agosto de 1914 \\
\hline Hospedaje de Huerta y Blanquet en Cádiz & 2 de septiembre de 1914 \\
\hline Huerta y Blanquet hacia Madrid & 4 de septiembre de 1914 \\
\hline Huerta ubicado en Barcelona & 20 de septiembre de 1914 \\
\hline Boda de Elena Huerta Águila & 21 de diciembre de 1914 \\
\hline Visita de Franz von Rintelen & Febrero de 1915 \\
\hline Visita de Enrique C. Creel & Febrero de 1915 al \\
\hline Huerta sale de España por el puerto de Cádiz & 31 de marzo de 1915 \\
\hline Llegada de Huerta a Nueva York & 12 de abril de 1915 \\
\hline Salida de Huerta hacia Newman, Texas & 24 de julio de1915 \\
\hline Aprehensión de Huerta & 27 de junio de 1915 \\
\hline Juicio contra Huerta & Julio de 1915 a enero de 1916 \\
\hline Fallecimiento de Huerta & 13 de enero de 1916 \\
\hline
\end{tabular}

ESTUDIOS DE HISTORIA MODERNA Y CONTEMPORÁNEA DE MÉXICO 55, enero-junio 2018, 159-194 DOI: http://dx.doi.org/10.22201/iih.24485004e.2018.55.64551 
resumidas cuentas: que se fuera a otro país. Ignorando tales directrices, Huerta, Blanquet y sus familias, abordaron un buque en Bristol para trasladarse a España. Desembarcaron en el puerto de Santander sin toparse con contratiempo alguno, ni restricción gubernamental. Al pisar tierra española, Huerta tuvo a su alcance cinco personas que formaron parte de su gabinete, y que vivían en San Sebastián: Manuel Mondragón, su ex secretario de Guerra y Marina. En forma adicional, figuraban Rodolfo Reyes, secretario de Justicia, Roberto A. Esteva Ruiz, subsecretario de Relaciones Exteriores, Adolfo de la Lama y José María Lozano. Adolfo de la Lama ocupó dos secretarías: la de Justicia y la de Hacienda, y José María Lozano, la de Instrucción Pública y Bellas Artes, y la de Comunicaciones y Obras Públicas. Al parecer, no se entrevistó con ninguno de sus ex colaboradores.

\section{Una ruptura inesperada entre Huerta y Blanquet}

Después de un breve descanso en San Sebastián, Huerta y Blanquet se dirigieron a Madrid, y se hospedaron en el mismo hotel, pero algo dramático sucedió. Algo que se ignora y que resulta imposible desentrañar. Los meses en que hicieron mancuerna en México en la conducción del país, la convivencia diaria en barco al cruzar el Océano Atlántico con destino al viejo mundo, y el desembarco, tocó a su fin. Estallaron los desacuerdos y casi de inmediato vino la ruptura. Nadie sabe cuál fue la verdadera razón, pero posiblemente se deba a que Blanquet, apoyado por Manuel Mondragón, opinó que para derribar a Carranza, se necesitaba un ejército, y que el lugar indicado para formarlo era los Estados Unidos, o Cuba, pero jamás España. Ahí no había suficientes mexicanos, y a los españoles no les llamaba la atención convertirse en mercenarios. Pero hubo otro factor desconcertante. Blanquet adujo, al igual que Mondragón, que la única forma de triunfar era tener como caudillo a Félix Díaz. La pregunta es, porqué los ex secretarios de Guerra y Marina le dieron la espalda a Huerta, y optaron por jugársela por una persona como Félix Díaz, que militarmente no garantizaba gran cosa. La respuesta es simple: más que huertistas, eran felicistas. Para mayor desgracia, Rodolfo Reyes, el redactor del Pacto de la Embajada, también se inclinó por Félix Díaz. En estas condiciones, a Huerta sólo le quedaba una 
carta en sus manos: José Refugio Velasco, y tampoco le fue mejor. Veamos: a la renuncia de Huerta a la Presidencia de la República, su sucesor, Francisco S. Carvajal, designó al general José Refugio Velasco como secretario de Guerra y Marina. Como la revolución se tornó incontenible, a escaso un mes, todo se derrumbó. José Refugio Velasco pactó con los grupos revolucionarios la rendición de la plaza, la disolución del ejército federal, y luego se dirigió a Veracruz para embarcarse en el vapor Alfonso XIII, con dirección a Europa. ${ }^{17}$ Junto con el general Francisco Salido, desembarcó en Santander, España. Sabía de sobra que Manuel Mondragón vivía en San Sebastián, Victoriano Huerta y Blanquet en Madrid, pero al parecer, no los buscó. Razones desconocidas, hicieron que José Refugio Velasco se aislara.

\section{El personal consular en España}

Justo, a la debacle del huertismo, el cuerpo diplomático se resquebrajó. Al calcular que su triunfo estaba próximo, Carranza envió a varios personeros a Europa en calidad de Enviados Extraordinarios o Agentes Diplomáticos para pregonar las bondades de la revolución constitucionalista. Sin portar el indispensable exequátur, lo primero que hicieron fue tratar de ser reconocidos por las autoridades españolas, y arrebatar los consulados al personal etiquetado de huertista. Como no fueron reconocidos de inmediato, realizaron una labor consular extraoficial, y fungieron como espías. Para los cónsules identificados con el viejo régimen, su labor se complicó. Se suspendió la recepción de sus haberes, y aunado a la presión de los agentes carrancistas, optaron por cerrar las oficinas consulares. Hubo quienes se resistieron a dejar el cargo, sin faltar los que cambiaron de casaca. En 1913, había 28 consulados distribuidos en otras tantas ciudades españolas, pero no obstante su número, en realidad cada uno tuvo escaso personal, cuya cifra total fue de 48 personas. El consulado de Barcelona tuvo cuatro y el de La Coruña tres. El resto, incluido Madrid, Cádiz, y Santander, sólo dos. El cónsul en Barcelona fue Inocencio Arriola, el de Madrid, Francisco A. de Icaza, el de San Sebastián, José Arce e Hijar, y el de Santander, Rafael

${ }^{17}$ Heraldo de Cuba, 21 de septiembre de 1914. 
Adalid. De todos ellos el más protagónico fue Inocencio Arriola, sobre el cual existen dudas acerca de quién lo designó: Huerta o Carranza. En la lista de los "Agentes y empleados consulares de México", etiquetados como huertistas, aparece su nombre, con un dato adicional: el de coronel huertista. En su expediente personal se dice que Carranza lo designó el 10 de julio Agente Comercial en Barcelona. Pero hubo algo más: para 1916, no tenía el indispensable exequátur. A la llegada de Huerta, ninguno de ellos, se le cuadró. Por otro lado, al parecer, Huerta no buscó a ninguno.

Varios agentes carrancistas llegados a Europa no tardaron en hacer gala de soberbia. Encaramado en el bando triunfante, Luis Quintanilla, que reemplazó a Francisco León de la Barra como ministro de México en Francia, mostró sumo desdén sobre los caídos en desgracia. Además de sus funciones protocolarias, en gran parte, su papel fue el de espía. El 16 de septiembre de 1914, desde París, le hizo saber a Juan Sánchez Azcona, a la sazón, Agente Confidencial del Gobierno Constitucionalista, quien se encontraba en Santander, que diariamente llegaban a la ciudad Luz, "una cadena de mejicanos, mejicanas y mejicanitos", todos ellos huertistas. Líneas más adelante agregó, que jamás se imaginó que hubiera tantos en París. En tono de conmiseración, afirmó que algunos tuvieron la osadía de acudir a sus oficinas en demanda de auxilio para paliar los estragos de la primera guerra mundial, y de su pésima situación económica. Unos le pedían ayuda para ser repatriados, y otros, para alimentarse. Luego lanzó dardos venenosos contra determinados huertistas. Expresó que tuvo frente a sí a Guillermo Rubio Navarrete, Gabriel Huerta, Guillermo Obregón, entre otros. Le solicitaron pasaportes y recomendaciones, que naturalmente les negó. ${ }^{18} \mathrm{En}$ otra carta dirigida a Miguel Díaz Lombardo, fechada el 19 de octubre de 1914, nuevamente hizo gala de displicencia sobre los perdedores. Sin mencionar sus nombres, expresó que en París solo quedaban dos “chinacos”. Luego afirmó que a causa del estallido de la primera guerra mundial, resultaba imposible que llegaran más mexicanos a Francia. Hubo cierre de fronteras y las autoridades no dejaban entrar más que a los franceses. ${ }^{19}$ En realidad, en París vivían algunas de las figuras clave de la política mexicana echados del país años antes por la

\footnotetext{
${ }^{18}$ SRE-AHD, leg. 343, f. 287 y 290.

19 Luis Quintanilla a Miguel Díaz Lombardo, 19 de octubre de 1914, en Valadés (2007, p. 94).
} 
revolución: Porfirio Díaz, José Yves Limantour, Francisco León de la Barra, y otros más, sin que Luis Quintanilla hiciera alusión explícitamente a ellos.

El 9 de julio 1915, Juan Sánchez Azcona le hizo saber a Isidro Fabela, que por entonces estaba en París, que se había topado con un grave problema en San Sebastián. El cónsul de la citada ciudad, José Arce e Hijar, de filiación huertista, se negaba a entregarle el consulado. El gobierno español lo apoyaba, pero no había forma de romper el protocolo. No sabían cómo retirarle el exequátur. Al parecer, la reticencia de Arce para entregar el cargo se debía a que estaba asesorado por el ex secretario de Hacienda, Adolfo de la Lama, y varios mexicanos que veraneaban en San Sebastián. Al final de cuentas, previa amenaza de utilizar la fuerza, las autoridades españolas le retiraron el exequátur a Arce, y lo obligaron a entregar las oficinas del Consulado. ${ }^{20}$ Otros miembros del cuerpo diplomático se refugiaron en España, país con el cual afirmaban tener cierta afinidad. Nos referimos a Alfonso Reyes y a Carlos Pereyra. El 18 de julio de 1913, Alfonso Reyes recibió el nombramiento de Segundo Secretario de la Legación de México en París. Su nombramiento fue firmado por Francisco León de la Barra, Secretario de Relaciones Exteriores del primer gabinete de Huerta. A la caída de este último, y el estallido de la primera guerra mundial, Alfonso Reyes dejó París y se trasladó a España. En sus escritos, habló maravillas del país ibérico. De sus viajes por toda la península, su convivencia con lo más granado de la intelectualidad española, y la buena comida. ${ }^{21}$ Nada de miseria ni de pobreza. Carlos Pereyra fungía como ministro de México ante el gobierno de Bélgica. A la renuncia de Huerta, Pereyra se apoderó de los fondos de la Legación, los repartió entre los empleados, y se dirigió a España. Su conducta sorprendió a sus conocidos quienes juraron que se trataba de una persona proba y seria. En todo caso, fue innegable su lealtad al gobierno que lo designó. ${ }^{22} \mathrm{~A}$ diferencia de Alfonso Reyes, a él no le fue bien y pasó apuros económicos. También debido a su calidad de integrante del extinto cuerpo diplomático, Amado Nervo permaneció en España, hasta que Carranza lo reinstaló, y envió al Uru-

\footnotetext{
${ }^{20}$ SRE-AHD, leg. 346, f. 195.

${ }^{21}$ Reyes (1941, p. 31).

${ }^{22}$ El Imparcial, 29 de julio de 1914; El Radical, 13 de octubre de 1914, y El Pueblo, 13 de octubre de 1914 .
} 
guay. Luis G. Pardo, el último ministro de México en Japón, amigo de Federico Gamboa, se refugió en Barcelona, donde seguramente se encontró con Huerta. ${ }^{23}$

\section{Los que arribaron a las costas españolas}

A la caída de Huerta, se registró el éxodo de sus colaboradores hacia distintas partes del mundo para escapar de la ira de los revolucionarios. Además de los altos mandos del ejército federal, salieron del país los integrantes de su gabinete, el episcopado, intelectuales, entre otros tantos. Para nuestros fines, un caso llama la atención. Nos referimos al subsecretario de Relaciones Exteriores, Roberto A. Esteva Ruiz. Por desavenencias con Huerta, en mayo de 1914, José López Portillo, renunció al cargo de secretario, y Esteva Ruiz lo reemplazó. Al avecindarse la caída del régimen, se dirigió a Veracruz y se embarcó en el vapor Alfonso XIII junto con su familia. Al arribar a costas españolas, tomó un tren que lo condujo a Madrid. Su intención era dedicarse a su profesión de abogado. ${ }^{24}$ El poeta Salvador Díaz Mirón, que dirigió el diario El Imparcial, salió de la ciudad de México al mismo tiempo que Huerta y Blanquet. Al llegar a Veracruz abordó el vapor Reina María Cristina rumbo a España. Al igual que otros mexicanos, desembarcó en Santander, instalándose en una modesta pensión. Apenas desembarcó, el cónsul de Barcelona, Inocencio Arriola, le telegrafió al agente comercial de Santander, que le informara de las actividades de cada uno de los que llamaba "huidos" que llegaban al puerto. Pero hubo una petición especial: que le informara de las conferencias dictadas por Díaz Mirón. ${ }^{25}$ Es casi seguro que el poeta se reunió con otros mexicanos ahí residentes tales como Rodolfo Reyes, Manuel Mondragón y Adolfo de la Lama. No tuvo la suerte de Rodolfo Reyes ni de su hermano Alfonso, y apenas vivió poco más de un año en Santander. Martín Luis Guzmán jamás militó en el bando huertista, sino en el villista. Por azares del destino, fue atrapado por las fuerzas carrancistas, y encerrado en Lecumberri. Pasados unos días, fue liberado, y a finales de 1914, tomó un

\footnotetext{
23 Gamboa (1995, p. 389).

24 Diario de la Marina, 20 de julio de 1914; Meyer (1983, p. 193).

25 SRE-AHD, leg. 343, f. 323-324.
} 
barco para cruzar el océano. Al tocar tierra firme, se dirigió a Madrid. Tuvo como vecinos en el mismo edificio a Alfonso Reyes y a Jesús T. Acevedo. El periodismo lo sacó a flote para sobrevivir, y publicó parte de sus obras como La querella de México. Cuando Federico de Onís dejó de publicar su columna crítica cinematográfica en la revista España, Martín Luis Guzmán y Alfonso Reyes la continuaron al alimón bajo el seudónimo de Fósforo. ${ }^{26} \mathrm{Al}$ distribuirse La querella de México, Rafael Adalid, encargado del consulado de Madrid, le envió un ejemplar al secretario de Relaciones Exteriores, Cándido Aguilar, afirmando que su contenido era totalmente adverso a la revolución. ${ }^{27}$

Caso aparte, es el referente al senador felicista Gumersindo Enríquez. En su calidad de vicepresidente del Senado, en febrero de 1913, acudió al Palacio Nacional acompañado de 25 senadores, para solicitarle a Francisco I. Madero su dimisión. Al enterarse de su misión, Madero envió al secretario de Hacienda, Ernesto Madero. ${ }^{28}$ Como era previsible, la respuesta fue negativa. Ese fue su pecado. Al avizorarse el triunfo del constitucionalismo, no quiso exponerse a perder la vida, y abandonó la ciudad de México. En Veracruz abordó un vapor para dirigirse a España. Al llegar ahí, se radicó en Barcelona. Resulta extraño que Indalecio Sánchez Gavito, miembro del Partido Liberal Democrático, creado en abril de 1913, para lanzar la candidatura de Félix Díaz a la Presidencia de la República, no se hubiera exiliado en los Estados Unidos, sino en España. ${ }^{29}$

Desde las vísperas del triunfo de los constitucionalistas, circularon rumores sobre infinidad de asesinatos políticos ocurridos durante los años 1913 y mediados de 1914. En realidad, las listas que han circulado, son ambiguas. Michael C. Meyer opina que el número total de víctimas puede alcanzar el centenar, pero al verificar los datos, el número se reduce, y a su juicio, es posible documentar con razonable certeza, 35 casos. Los nombres se repiten en la literatura revolucionaria, destacando los consabidos Francisco I. Madero, Pino Suárez, Belisario Domínguez, Abraham González, el diputado Serapio Rendón y el poeta Solón

\footnotetext{
${ }^{26}$ Bruce-Novoa (1987, p. XVI-XVIII).

27 SRE-AHD, leg. 17-6-160.

${ }^{28}$ De cómo vino Huerta y cómo se fue (1975, p. 107).

29 Liceaga (1958, p. 270, 271).
} 
Arguello, entre otros. ${ }^{30}$ Se sabe que, sin esperar que los constitucionalistas llegaran a la ciudad de México, tres de los involucrados en algunos de los asesinatos se dirigieron a Veracruz para embarcarse rumbo a Europa: Francisco Chávez, Celso Acosta y Felipe Fortuño Miramón. El 17 de octubre de 1914, el cónsul Inocencio Arriola informó a Juan Sánchez Azcona, que había llegado a Barcelona la familia Duret, y con ellos, el "famosísimo Fortuño Miramón”, quejándose de que los constitucionalistas se habían apropiado de las casas de los perdedores. Felipe Fortuño Miramón fue señalado como cómplice en el asesinato del diputado Serapio Rendón. ${ }^{31} \mathrm{Al}$ iniciarse el año de 1915, el mismo cónsul detectó la presencia en Barcelona de Francisco Chávez, el ex Inspector General de Policía, vinculado a varios asesinatos, entre ellos, el del poeta nicaragüense Solón Arguello. A propósito de ello, Inocencio Arriola, expresó en forma festiva, que todo indicaba que a Huerta le había dado pulmonía, lo que le impedía salir a la calle. Si salía a la calle, corría el riesgo de toparse con Chávez, quien con seguridad le pediría dinero. Como la tardanza en ver a Huerta lo tenía desesperado, Chávez amenazaba con hablar más de la cuenta. Difundir detalles sobre los crímenes que le achacaban. Para no perder detalles, Arriola comisionó a un agente para que lo siguiera muy de cerca. Arriola se enteró que el Inspector General de Policía, se reunía con varios militares huertistas, así como con algunos españoles, que sospechaba habían sido policías secretos a su servicio. Sin aportar más detalles, supo que Chávez estaba a punto de embarcarse en el vapor María Cristina, sin saberse hacia dónde..$^{32}$ Debido a que no estuvo dispuesto a perder la vida a manos de los carrancistas, Celso Acosta, Inspector de Policía del Distrito Federal, salió del país y se exilió en España. El cargo lo ejerció justo cuando fueron asesinados Madero y Pino Suárez. Los sabuesos de Arriola revelaron que Celso Acosta había dejado Barcelona y dirigido a San Sebastián, ciudad en la cual era propietario de una casa. Como su esposa no tenía fortuna, se sospechaba que la compró con dinero robado en México. ${ }^{33}$ Entre paréntesis, Inocencio Arriola hizo mofa del ex secretario particular de Blanquet, Manuel

\footnotetext{
30 Meyer (1983, p. 153, 154).

${ }^{31}$ Mellado (1914, p. 73).

32 SRE-AHD, leg. 346, f. 30.

33 SRE-AHD, leg. 346, f. 24-25.
} 
Vidaurrázaga. Le espetó a Sánchez Azcona, que vivía de las migajas que le proporcionaba la señora María de Jesús Olivos, esposa de Blanquet. No obstante que su situación económica era muy desgraciada, afirmaba que era merecida. ${ }^{34}$

En febrero de 1914, estando en la madre patria, el torero Rodolfo Gaona se enteró que Victoriano Huerta había sido echado de la silla presidencial. Al mismo tiempo, recibió la noticia que Carranza había prohibido las corridas de toros, y sus amigos le recomendaron abstenerse de firmar contrato alguno para torear en México. Pero hubo algo más: el matador recibió un cable procedente de México, en el que lo acusaban de ser enemigo político del Primer Jefe, a causa de su amistad con Huerta y Blanquet. ${ }^{35}$ A Gaona no le quedó más que permanecer en España. Basado en el diario ABC, editado en Madrid, Oscar Flores habla de un desembarco en el puerto de Cádiz que tuvo lugar en agosto de 1914. Entre los recién llegados menciona al obispo de San Luis Potosí, Ignacio Montes de Oca, al hijo de Victoriano Huerta, que llevaba el mismo nombre, José María Lozano, exsecretario de Instrucción Pública y Bellas Artes, y también de Comunicaciones y Obras Públicas, Jesús Acevedo, Manuel Vidaurrázaga, secretario particular de Aurelio Blanquet, Ricardo Gómez Robelo, exprocurador General de la República, y numerosos oficiales del ejército federal. ${ }^{36}$ Todo indica que se trataba del vapor Buenos Aires, mencionado por la prensa cubana. ${ }^{37}$ De entre los recién llegados, destaca el obispo Ignacio Montes de Oca quien tenía la intención de llegar a Roma. Por tales días estalló la primera guerra mundial sin saberse si llegó a su destino. Sus contactos privilegiados le permitieron pasar largas temporadas en palacios de amigos en Madrid, Cádiz, Jerez y otras ciudades. ${ }^{38}$ Hubo más mexicanos que para entonces, ya vivían en el país ibérico. Tres casos notables llaman la atención: Fernando Pimentel y Fagoaga, Pablo Macedo y Gabriel Fernández Somellera, los dos primeros del grupo de los “científicos”. Pimentel y Fagoaga se avecindó en Madrid y en Barcelona, y Pablo Macedo en Madrid. El primero hizo gala de su talento en el mundo de los ne-

\footnotetext{
34 SRE-AHD, leg. 346, f. 25.

35 Gil Blas, 26 de febrero de 1914, y Padilla (1987, p. 276, 277).

36 ABC, Madrid, 19 de agosto de 1914, citado por Flores (2001, p. 483).

37 Diario de la marina, 31 de julio de 1914.

${ }^{38}$ Valverde Téllez (1949, p. 101).
} 
gocios y fundó compañías pavimentadoras de calles y una empresa de bienes raíces. Con el segundo, la suerte fue distinta: la depresión lo hizo su víctima. El tercero, Gabriel Fernández Somellera, fue director del diario católico La Nación, y llegó a España huyendo de posibles represalias de Huerta.

\section{Huerta hacia Barcelona}

Como se ha visto, no obstante su condición de exJefe de Estado, en ningún momento las autoridades españolas mostraron deferencia alguna hacia Huerta, y el Ministerio de Gobernación lo sometió a una discreta vigilancia. Siguieron sus pasos día con día. A raíz del inicio de la primera guerra mundial, lo mismo hicieron los servicios de inteligencia británicos y alemanes. ${ }^{39}$ Con Rodolfo Reyes, un simple exsecretario de estado, involucrado en el golpe de Estado contra Francisco I. Madero, la situación fue distinta ya que afirma que llegó a conversar con el Rey Alfonso XIII, y a jugar el tiro al pichón..$^{40}$ En el aislamiento y soledad completa, Huerta y su familia abandonaron el hotel de Madrid, y se dirigieron a Barcelona, ciudad en la cual permanecerían los siguientes siete meses. Se calcula que llegaron a la citada ciudad en septiembre de 1914. Se trasladó junto con varios de sus hijos, incluidos sus yernos, el catalán Francisco Colom, Luis Fuentes y Alberto Quiroz. Una de sus hijas se casó precisamente en Barcelona. En un momento, Huerta y su familia viajaron a Guipúzcoa, región natal del abuelo de Emilia, su esposa. También viajaron a Granada para visitar la célebre Alhambra. Se dice que en una ocasión compartió una botella de coñac y una hora de conversación con Juan Belmonte, uno de los más famosos toreros de la época. Por la gran amistad que existía entre Huerta y Gaona, es probable que se hayan encontrado en Madrid o Barcelona, recordando sus días de gloria en México, y también sus desgracias. En realidad, la vida familiar del torero fue turbulenta y desastrosa. Su esposa española, Carmen Ruiz de Moragas, se hizo amante del monarca Alfonso xIII, sin quedarle otra alternativa que el divorcio. ${ }^{41}$

\footnotetext{
39 Meyer (2001, p. 138).

40 Reyes (1948, p. 28, 29).

${ }^{41}$ Revista de revistas, n. 346, 17 de diciembre de 1916; el n. 382 del 26 de agosto de 1917, y Padilla (1987, p. 303).
} 
El matador alternó en España con lo más granado de la tauromaquia, entre otros José Gómez Joselito y Juan Belmonte, con los cuales entabló una gran rivalidad. Participó en las principales ferias españolas: en Sevilla, Valencia, Salamanca, Pamplona, Santander, Madrid, Bilbao, San Sebastián.

\section{El cónsul Inocencio Arriola contra Huerta}

El 17 de octubre de 1914, Inocencio Arriola, cónsul en Barcelona, dio inicio a una labor destructora sobre Huerta y los mexicanos ahí residentes. Le informó a Juan Sánchez Azcona, residente en Madrid, que un tal Rawner, posiblemente Abraham Ratner, cercano a Huerta, realizaba negocios bancarios en el Hotel Continental por un monto calculado en tres o cuatro millones de pesetas. Agregaba que este personaje se especializaba en vender acciones de algunas empresas mexicanas, entre ellas, la del "Popo", posiblemente minera. Aseveró que para sobrevivir en Barcelona, Huerta llevaba consigo giros de diferentes bancos europeos, y barras de oro en cantidad considerable, aunque luego salió con que se trataba de simples rumores. Pero lo que resultaba descabellado fue la afirmación de Inocencio Arriola consistente en que Huerta se dedicaba a vender billetes del Banco Nacional de Francia, seguramente falsificados. ${ }^{42}$ Dispuesto a no perderlo de vista, reportó que Huerta se cambió de domicilio. Dejó el ubicado en la calle Bailen, un piso por el cual pagaba 25 pesos al mes, y trasladado a un chalet cerca de Tibidabo, un cerro ubicado en las orillas de Barcelona. Con la intención de provocar escarnio, el mismo cónsul envió a Sánchez Azcona un ejemplar de El Día Gráfico que difundió la que llamaba "boda suntuosísima de la hija del Traidor Huerta”, a la que concurrieron las más altas personalidades, como el judío Ratner, y dos curas hispanos que salieron de México gracias a los buenos oficios de Huerta. Eso sí: no concurrió ninguna autoridad española. Agregó que durante la fiesta se abusó del Himno Nacional. ${ }^{43}$ En el mismo tenor, Juan Sánchez Azcona le hizo saber a su correligionario, Miguel Covarrubias, que para el mes de noviembre de 1914, España estaba plagada de huertistas, sin saber exactamente cuáles eran sus propósitos. Algunos acariciaban la idea de

\footnotetext{
42 SRE-AHD, leg. 343, f. 414.

43 SRE-AHD, leg. 343, f. 457.
} 
reconquistar el poder, pero el problema era que estaban muy divididos, y se quejaban de que Huerta los había abandonado. Remataba afirmando que Huerta se la pasaba en Barcelona en eternas libaciones. ${ }^{44}$

\section{Inocencio Arriola y los expatriados}

En general, Inocencio Arriola, tuvo una actitud despectiva hacia los expatriados. A su juicio, la colonia mexicana, aparte de los clérigos y seminaristas, que ya residían en Barcelona, aumentó con la llegada de los que huían de los países europeos envueltos en la primera guerra mundial. Un segundo grupo estaba integrado por personas pudientes, hacendados y empresarios, cuyos intereses habían sido tocados en México, en forma fatal, pero necesaria. Cruzaron el océano para escapar de la ira de los jefes revolucionarios. El tercer grupo incluía al personal político, acusado de colaborar con Huerta tanto en el golpe de Estado, como en el asesinato de Madero y Pino Suárez. Ninguno de ellos simpatizaba con la revolución. Un cuarto grupo agrupaba a los aventureros internacionales que, utilizando una serie de triquiñuelas, sorprendían a la persona más experimentada. Todo ello, haciendo gala de ser gente decente. ${ }^{45} \mathrm{Al}$ parecer, a los que más odiaba Arriola, era a los políticos expatriados. A Saúl Elorduy, supuesto capitán de las fuerzas huertistas, constitucionalistas, y villitas, lo acusó de vulgar aventurero, y a otros, de malagradecidos. ${ }^{46}$ Pero hubo un suceso que caracterizó en todo su arrogante personalidad. Veamos: en los días siguientes de la salida de Huerta rumbo a los Estados Unidos para montar la contrarrevolución, su esposa Emilia Águila y sus hijos, se hicieron presentes en las oficinas del consulado de Barcelona para obtener el pasaporte, y así poder viajar al nuevo mundo, topándose con algo inaudito. Inocencio Arriola asumió una postura inesperada. De hecho, los insultó. El 12 de abril de 1915, en forma festiva y burlesca, el cónsul le narró el suceso a Juan Sánchez Azcona. Afirmó que le negó a Jorge Huerta el pasaporte, lo cual derivó en un fuerte altercado. Pero no sólo se lo negó a él, sino a "todas las Kakas como cariñosamente llamaban a

\footnotetext{
44 SRE-AHD, leg. 343, f. 323, 324.

45 SRE-AHD, leg. 735, expediente 1-6-18.

46 SRE-AHD, leg. 735, expediente 1-6-18.
} 
todas las hijas y señoras de Huerta en México”. En forma adicional, Arriola envió una circular a los consulados de su resorte para que se abstuvieran de otorgar los ansiados pasaportes. A juicio de Arriola, a la familia de Huerta no le quedó otra alternativa que recurrir al consulado de los Estados Unidos. ${ }^{47}$

En agosto de 1918, José Moreno se quejó ante Cándido Aguilar, titular de Relaciones Exteriores, por conducta mostrada por Inocencio Arriola ante los mexicanos que acudían al consulado de Barcelona. Expresaba que la obligación de todo cónsul era prestar ayuda a los mexicanos, no material, pero sí moral. Entre otras cosas, le solicitó un pasaporte gratuito, por carecer de fondos, pero le fue negado; le pidió autorización para que sus familiares le dirigieran la correspondencia al consulado, sin resultado alguno. Arriola le advirtió que de recibir correspondencia alguna en el consulado, la devolvería al remitente. Por estas y otras razones, Moreno aseguró que existía una brecha entre la colonia mexicana residente en Barcelona, y el cónsul, al grado que era enemiga del gobierno que representaba. Para concluir, le sugirió a Cándido Aguilar, que vigilara la vida privada de Inocencio Arriola, la cual no era precisamente honorable. Esteban González, quien trabajaba en la Compañía Barcelonesa de Electricidad, se quejaba de que cada vez que iba al Consulado, Arriola lo amenazaba con entregarlo a la policía. En venganza, acusó a Arriola de cocainómano, depravado, y frecuentar cabarets ubicados en los suburbios para divertirse con mujerzuelas. ${ }^{48}$

Pero Arriola llegó a asegurar que en realidad trataba bien a los mexicanos. Pruebas: el 15 de septiembre de 1918, recibió a lo más distinguido de la colonia mexicana en el Consulado, entre ellos el ex senador Gumersindo Enríquez, para celebrar las fiestas patrias. A la hora del brindis, Enríquez tomó la palabra para alabar la actitud patriótica de Carranza ante los conflictos internacionales, secundado por una persona apellidada Martínez del Campo. De paso, Enríquez le hizo un guiño a Carranza recordando que fueron compañeros en el senado. Inclusive, Arriola se jactó de buscar empleo a varios mexicanos en la compañía Riegos y Fuerza del Ebro, aunque no todos querían trabajar. Algunos abandonaban el empleo el primer día, y otros ni siquiera se presentaban alegando que

\footnotetext{
47 SRE-AHD, leg. 346, f. 117.

48 SRE-AHD, leg. 735, expediente 1-6-18.
} 
no era un empleo acorde con su nivel educativo. En los talleres colocó entre cinco y seis personas y en las oficinas a otros tantos, figurando entre ellos Luis del Toro, Emilio Sola, Luis G. Pardo, y Manuel Vidaurrázaga. ${ }^{49}$ El primero pudo ser el ex director del diario El Independiente, famoso por consignar en sus páginas las corridas de toros en las que intervino Rodolfo Gaona y los brindis en honor a Huerta..$^{\circ}$ En realidad, Arriola los colocó gracias a los buenos oficios de otro expatriado, Carlos Paliza.

\section{Cero extradiciones, hostilidad y desesperación entre los exiliados}

Atrapado en la tarea de pacificar el país, vía la liquidación militar de villistas, zapatistas, huertistas, porfiristas, y otros, Carranza no tuvo tiempo ni interés en gestionar ante las autoridades españolas la extradición de algún mexicano vinculado al régimen de Huerta. El 24 de abril de 1916, una persona que firmaba con las siglas Q. E. S. M., le preguntó a Sánchez Azcona si era cierta la noticia de que el gobierno mexicano había solicitado la extradición del que fuera presidente del Senado, Gumersindo Enríquez, y de Indalecio Sánchez Gavito, radicados en España. ${ }^{51} \mathrm{Al}$ día siguiente, o sea el 25 de abril de 1916, otra persona, que también firmaba con varias siglas, y que al parecer era Juan Sánchez Azcona, quien operaba desde Madrid, le hizo saber a Manuel de Figuerola y Ferreti, que no portaba "instrucción alguna de solicitar al Gobierno Español la extradición de ningún mexicano residente en España”. Ni antes ni después de su llegada a este país. ${ }^{52}$ Pero el destierro no resultó placentero para los exiliados. En su Diario, Federico Gamboa, refugiado en La Habana, y contactado por los mexicanos que iban al viejo mundo, y a la inversa, hizo un juicio devastador sobre su situación económica. A propósito de una escala que hizo Concha Miramón de Duret en abril de 1916 en La Habana, procedente de Barcelona, esta última le pintó un cuadro dramático. En forma textual, expresó:

\footnotetext{
49 SRE-AHD, leg. 735, expediente 1-6-8.

${ }^{\circ}$ El Independiente, 24 de noviembre de 1913; y 12-13 de enero de 1914.

${ }^{51}$ SRE-AHD, leg. 355, f. 115.

52 SRE-AHD, leg. 355, f. 116.
} 
iTodos náufragos! Fernando [su esposo] sin hallar qué hacer y neurasténico perdido; Pablo Macedo peor, casi no sale a la calle; don Gumersindo Enríquez con estrecheses monetarias y roído de murrias; Victoriano Salado Álvarez también sin trabajo - parece que en España nadie lo halla- llora a propósito de cuanto hay; Carlos Pereyra en vísperas de trasladarse a la Argentina contratado en un diario, y su mujer al frente de una casa de asistencia por cuenta propia.

¡Qué sé yo cuántos más! Larga lista de dramas familiares que no se conocen. iEl desastre colectivo de un enorme grupo! ${ }^{53}$

\section{Un juicio adverso contra Huerta}

Edmundo González Blanco, un escritor español poco conocido en México, afirma que en 1916 se reunió en Madrid con un grupo de amigos, partidarios del movimiento revolucionario, para divulgar la verdad de lo ocurrido en México. A raíz de ello, escribió cuando menos tres libros. Uno de ellos se titula Carranza y la revolución de México. En un apartado aborda la llegada de Huerta a España. En forma un tanto sarcástica expresó, que Huerta desembarcó una mañana gris en Santander, un puerto al cual lo llevó un buque inglés. Narró que el general pasó en forma fugaz, como un relámpago, y nadie le hizo caso. Ya en tierra firme, compró un cesto de sardinas, e hizo saber a alguien que lo saludó, que planeaba viajar a diversas partes de la península. ${ }^{54}$ González Blanco aseguró que horas más tarde, Huerta habló con los periodistas quienes le pidieron su opinión sobre la guerra recién desencadenada en Europa, y sobre la situación reinante de México. Sin especificar cuáles fueron sus respuestas, afirmó que algunos periodistas quedaron desconcertados, sin faltar quienes dudaron entre indignarse, o bien tomar sus palabras a broma. Al poco rato, todos cayeron en la cuenta de que en realidad no valía la pena indignarse. ${ }^{55}$ Algo desafortunado externó Huerta en la entrevista, que un periodista se retiró ofendido por una expresión alusiva

\footnotetext{
53 Gamboa (1995, p. 335, 336).

54 González Blanco (1916, p. 548).

55 González Blanco (1916, p. 547, 548).
} 
a los españoles. Es probable que se tratara de la palabra pícaro, con la cual meses atrás designó a los españoles. Entrando al terreno de la defenestración completa, González Blanco afirmó que la vida de Huerta estaba colmada de atrocidades, lo cual lo condenaba a vagar sin rumbo por el mundo. Lo describió como una persona con "la cara dura, sin una línea delicada y flexible, la tez bronceada, el bigote recio y cerdoso y la mirada jaspeada de rojo, como si reflejara charcos de sangre”. Líneas más adelante expresó:

No tiene la altivez del caudillo, ni la marcialidad del soldado, ni la finura del diplomático. Con aquellos calzones en que iban metidas sus piernas, y aquel fachoso sombrero de tela, tenía un aspecto lamentable. Este general, que se atreve llamar bandido a Villa y viene a España a hablar mal de los españoles, quiso luego hacer el elogio de nuestra tierra. A un cochero le da un duro para que se lo gaste en vino; a unos músicos ambulantes les obsequia con una botella de manzanilla y él mismo se regala unas copas de Jerez..$^{56}$

En otra parte de su obra, González Blanco afirmó que un torero ignorado le tendió la mano, "no en señal de saludo precisamente. iTodo castizo, muy castizo!”. No especificó si se trababa de Belmonte o Rodolfo Gaona. Lo culpó de tener el hábito de colgar en los cocoteros racimos de españoles, todo ello al calor del consumo de vinos españoles, y que en un momento dado, intentó ser galante con las españolas utilizando frases vulgares como la que dicta: "iQué buenas hembras hay aquí!”. Para González Blanco, se trataba de un sujeto despreciable que atendía "Todos los negocios de Estado, o la mayoría de ellos, quizás los más importantes”, a bordo del automóvil de la Presidencia, con el escudo nacional, parado frente a las casas públicas, y aún en las tabernas. ${ }^{57}$

Para rematar, en tono despectivo, González Blanco lanzó un juicio devastador. Expresó: ¿Y a un hombre de esta calaña, valdría la pena pedirle su opinión sobre la guerra que asolaba a Europa? La respuesta fue, no. Con llevarlo como catador de vinos y licores a una bodega de la Rioja era más que suficiente. Pero lo mejor sería impedir que las plantas de sus pies siguieran manchando España,

${ }^{56}$ González Blanco (1916, p. 549, 550).

57 González Blanco (1916, p. 551). 
tierra de soldados y poetas, "sobre la que él ha puesto una sombra, como un crespón de luto". ${ }^{8}$ Retomando sus preguntas iniciales, el citado autor concluyó que lo expresado por Huerta en la entrevista, y su conducta mostrada en España, eran más que suficientes para corroborar todo lo siniestro y abominable que de él se decía. Por ende, resultaba insultante dejarlo vivir en España. Como se infiere, González Blanco, cuyo libelo fue pagado por los carrancistas, sugería echar a Huerta de España. Casi de inmediato, Luis Quintanilla, quien como se ha advertido, estaba al frente de la Legación de México en París, le pidió a Sánchez Azcona, que el libro fuera traducido al francés, para aplacar las voces inmundas de los reaccionarios que por ahí pululaban. ${ }^{59}$

Pero la indiferencia, cuando no el desprecio hacia Huerta y seguidores, fue extensiva hacia los carrancistas, incluidos los miembros del cuerpo diplomático, algunos de los cuales se jactaban de intelectuales. Según Lorenzo Meyer, en 1918, en el Salón Pompeya de Madrid, solía cantarse La Cucaracha, como un cuplé, injuriando a Carranza. Pero lo peor fue que Amado Nervo y Luis G. Urbina, fueron etiquetados de "poetastros y literatillos completamente menospreciados". ${ }^{60}$ No obstante su supuesto acendrado hispanismo, el segundo, un connotado huertista, renegado para más señas, fue objeto de un desprecio brutal.

\section{La visita de Rintelen: la contrarrevolución}

Como se ha señalado, no obstante que España fue uno de los países que inmediatamente reconocieron su gobierno en febrero de 1913, a su llegada a España, Huerta no fue objeto de ningún trato especial. El menosprecio, la indiferencia y la vigilancia fue el pan de cada día. Utilizando un poco de sentido común, el ex mandatario se dio cuenta de todo ello, y que en realidad era un apestado, razón por la cual carecía de sentido continuar viviendo ahí. Sus ex aliados, Mondragón, Blanquet y Rodolfo Reyes, le habían dado la espalda. Por lo demás, existía el riesgo de que los constitucionalistas, ya afianzados en el poder, tramitaran su extradición y le cortaran la cabeza. Barbara W. Tuchmann, afirma que

\footnotetext{
$5^{8}$ González Blanco (1916, p. 551).

59 SRE-AHD, leg. 346, f. 94.

60 Meyer (2001, p. 197).
} 
desde 1914, el general Huerta había estado tramando en Barcelona, como Napoleón en la Isla de Elba, el momento de su regreso. ${ }^{61} \mathrm{~A}$ juicio de Michael $\mathrm{C}$. Meyer, Huerta rumiaba su desgracia, y rápidamente empezó a fraguar su retorno a México. A principios de diciembre de 1914 visitó la Embajada Británica en Madrid. Al hablar con el embajador se quejó del severo invierno español, y del disfrute de su estancia fugaz en Jamaica. Acto seguido le preguntó si el gobierno de Su Majestad le permitiría su regreso a la isla, o bien en otra posesión británica de las Indias Occidentales. En respuesta se le indicó, que en vista de la perturbación que aun privaba en México, lo mejor sería Cabo Verde, las Islas Canarias, o bien Madeira, donde el clima era similar. Por supuesto que tales opciones no le interesaban.

Según George J. Rausch, el 15 de febrero de 1915, Huerta recibió la visita de una comisión alemana encabezada por el capitán Franz von Rintelen, oficial de la marina de guerra, vestido de civil, quien le ofreció respaldar un golpe militar que lo reinstalara en el poder en México. ${ }^{62}$ Von Rintelen era una persona inteligente, audaz y un tanto megalómano, atributos importantes de todo agente secreto. Contaba con 38 años de edad, era alto, bien parecido, de buena familia, vestía impecablemente, hablaba el inglés a la perfección, y conocía a fondo los Estados Unidos, México y América del Sur. En un grueso leg. disponible en la Secretaría de Relaciones Exteriores, el cual contiene una serie de artículos tanto a favor como en contra de Huerta, no aparecen indicios de que Inocencio Arriola, o Sánchez Azcona, hayan detectado el acercamiento de Von Rintelen con Huerta en Barcelona. Al parecer, el hecho pasó desapercibido. Pero no sólo eso, sino que en forma inexplicable, en sus memorias, Franz von Rintelen, ubica la primera entrevista con Huerta en Nueva York, en lugar de Barcelona. Lo cierto es que fue en Barcelona. Afirma que hizo malabares para descubrir en dónde residía. Una vez que tuvo el dato, fue a buscarlo a un hotel. Huerta estaba sentado en un salón, y se mostró sorprendido al ver que lo saludaba un extraño. Von Rintelen le confió que era un militar alemán, y el interés que tenían en apoyarlo en todo lo que fuera necesario para recuperar el poder. Huerta se mostró temeroso que fuera un agente americano quien le tendía una celada. Guardó silencio,

\footnotetext{
61 Tuchman (2010, p. 99).

62 Rausch (1962, p. 135).
} 
y después de una serie de vacilaciones, se convenció de que no se trataba de un agente de los Estados Unidos. Von Rintelen le expuso las razones que tenía para visitarlo. La principal: que a Alemania le urgía desencadenar una guerra entre México y los Estados Unidos, ya que absorbería gran parte de las municiones que este último país enviaba a sus aliados europeos inmersos en la primera guerra mundial. A su vez, Huerta le informó que sus correligionarios en los Estados Unidos habían iniciado los preparativos para una revolución en México, pero que carecían de armas y de dinero. Hablaron de los planes en caso de que la revolución triunfara. Huerta puso como condición que los submarinos alemanes desembarcaran gran cantidad de armas en las costas mexicanas, el suministro de fondos abundantes para adquirir el material necesario, y que el gobierno alemán brindara apoyo moral a México. Bajo tales premisas, el gobierno presidido por él tomaría las armas contra los Estados Unidos. Después de la entrevista, von Rintelen envió un cable informativo a Berlín. En realidad, Huerta se interesó en el plan, pero se abstuvo de comprometerse del todo en forma inmediata. Antes de abandonar Barcelona, von Rintelen le prometió que seguirían en contacto. ${ }^{63}$

\section{Porfirio Díaz Jr.: ¿Cabeza de un movimiento contrarrevolucionario?}

Los mexicanos exiliados en España estuvieron lejos de crear un organismo que los aglutinara para defenderse de una eventual amenaza de extradición por parte del gobierno de Carranza. En parte, porque salvo Huerta, y posiblemente Rodolfo Reyes, no hubo otra persona con capacidad de convocatoria. En los Estados Unidos fue formada la Asamblea Pacificadora Mexicana en la cual figuró Federico Gamboa, que buscaba un acercamiento civilizado con los jefes revolucionarios, y la Junta Revolucionaria de Nueva York, obra de Félix Díaz, cuyas intenciones eran penetrar en México con las armas en la mano para derrocar a Carranza. ${ }^{64}$ Lo único sabido, es algo que tuvo tintes trágico cómicos. Un personaje bastante obscuro, Gonzalo Enrile, que jugó un papel secundario en la rebelión de Pascual Orozco contra Madero en 1912, entró en escena. Al

63 Rintelen (1942, p. 132, 133).

64 Liceaga (1958, p. 395). 
avizorarse el triunfo de Carranza se exilió. A principios de 1916 vivía en La Habana, haciéndose pasar como coronel del ejército federal, lo cual era falso. Fue expulsado de la isla al ser denunciado de fungir como agente del imperio teutón. ${ }^{65}$ Llegó a Madrid en febrero del citado año y se hizo presente en la embajada alemana portando una carta de recomendación de su viejo conocido, el agregado militar en los Estados Unidos, Franz von Papen. En forma descabellada, aseguró ser el representante de todas las fuerzas anticarrancistas, incluidos los felicistas, villistas, zapatistas, y otros. ${ }^{66} \mathrm{El}$ dato concuerda con otro aportado por el cónsul carrancista en La Habana, Antonio Hernández Ferrer, quien hizo un informe al director General de Consulados, fechado el 24 de enero de 1916, en el cual afirmaba que Gonzalo Enrile viajaba a San Sebastián, España. Con qué finalidad: convencer al hijo de Porfirio Díaz para que jefatura un movimiento tendiente a derrocar al Primer Jefe. En caso de que Porfirio hijo aceptara, contaría con el apoyo del clero, de los científicos, e incluso de villistas y zapatistas. ${ }^{67}$ Se ignora si en realidad viajó a San Sebastián. Lo que sí es cierto, fue que viajó a Berlín, y pidió ayuda para montar un movimiento contrarrevolucionario en México. El gobierno alemán le dio respuestas corteses, pero ambiguas. A la postre, sus planes fracasaron.

\section{Huerta hacia los Estados Unidos}

Consciente de que no era una persona grata en España, y que estaba siendo vigilado por el sistema de espionaje alemán, español, mexicano, y posiblemente americano, Huerta aceleró su salida de España. Pasarse el resto de sus días soportando ataques y descortesías de todos lados, no resultaba placentero. Lo más dramático fue que los mexicanos de tinte civil, que salieron al exilio al mismo tiempo que él, a los cuales benefició, le hicieron el vacío. Pero hubo un hecho crucial. A su intelecto, no escapó que si bien, Blanquet y Mondragón le dieron la espalda en España, en los Estados Unidos contaba con el apoyo y la simpatía de Pascual Orozco, y de gran parte de los altos mandos del extinto

\footnotetext{
${ }^{65}$ Revista mexicana, n. 100, San Antonio, Texas, 5 de agosto de 1917, sin página.

66 Katz (1982, p. 15-17)

67 SRE-AHD, L-E-796.
} 
ejército federal. En vista de ello, decidió jugarse la vida en una intentona contrarrevolucionaria, sin descartar el eventual apoyo alemán interesado en crear un distractor en el nuevo mundo. A resultas de ello, Huerta abandonó España. Según George J. Rausch, el 31 de marzo de 1915 salió de España por el puerto de Cádiz en el vapor Antonio López, de la Compañía Trasatlántica Española. ${ }^{68}$ Se dice que llegó diez días más tarde a Nueva York. Rausch da como fecha de su arribo el 12 de abril, lo cual indica que el viaje duró unas dos semanas. Huerta sabía que su cruzada era sumamente arriesgada, y que de fallar, su suerte sería el martirio. Al enterarse de su inminente llegada a los Estados Unidos, el cónsul general carrancista, Ramón P. de Negri, se dirigió el 9 de abril a todos los cónsules asignados en los Estados Unidos, para que solicitaran al presidente Wilson poner tras las rejas a Victoriano Huerta, ya que era un prófugo de la justicia:

Muy cordialmente invito a todos mis compañeros en el honroso Servicio Consular Constitucionalista en este país, se dirijan en enérgico y patriótico mensaje al Hon. Presidente Wilson, con motivo del arribo a costas americanas del asesino Victoriano Huerta, solicitando sea arrestado y retenido en las prisiones americanas, hasta ser entregado al Gobierno mexicano, por ser un prófugo de la Justicia de nuestro país.

Muchas razones de peso nos asisten para solicitar el cumplimiento de la Ley, entre ellas que Huerta cometió el crimen de asesinar al presidente y vice-presidente reconocidos legalmente por los Estados Unidos y todos los países del orbe, agregando a estas razones legales, las del humanitarismo, como es el dejar libre a un asesino. ${ }^{69}$

La presencia de Huerta en los Estados Unidos dio lugar a toda una serie de especulaciones. Una de ellas, que había sido expulsado de España, lo cual negó. Huerta declaró que sus enemigos políticos en Nueva York, a los cuales

\footnotetext{
${ }^{68}$ Rausch (1962, p. 135).

69 SRE-AHD, L-E-819.
} 
identificaba como "istas", eran los responsables de tal información..$^{70}$ En realidad, quien difundió la versión de su supuesta expulsión de España, fue Pedro González Blanco, hermano de Edmundo, su detractor, autor del libelo citado, quien estaba de visita en Nueva York. ${ }^{71} \mathrm{El} 11$ de mayo de 1915, apareció en el New York Times, una nota en la cual se afirmaba que en ningún momento el gobierno español le pidió a Huerta que abandonara la península, que nada tuvo que ver con su partida hacia los Estados Unidos, así como que tampoco le impuso restricciones para que en el futuro pudiera entrar o salir de España. ${ }^{72}$

\section{Blanquet y Mondragón hacia los Estados Unidos}

Así las cosas, el 28 de abril de 1915, una persona cuyo nombre no aparece en la fuente consultada, le informó al cónsul Inocencio Arriola, que Aurelio Blanquet y cuatro militares más, dejaron Madrid rumbo a San Sebastián para tramitar sus pasaportes en el consulado de esta ciudad. Agregó que tenía informes fidedignos de que Blanquet planeaba tomar un barco para cruzar el océano. Efectivamente, el viaje de Blanquet a los Estados Unidos realmente ocurrió. El 9 de mayo de 1915, El Demócrata, de filiación carrancista, difundió un cable procedente de Eagle Pass, que decía que Blanquet salió de San Sebastián, con dirección a Nueva Orleans, paraíso felicista, y que seguramente se instalaría en San Antonio, Texas. Al cotejar las fechas, sucede que el viaje de Blanquet y Huerta fue casi simultáneo. La diferencia fue cosa de días. ${ }^{73}$ Manuel Mondragón no se quedó atrás. Si bien tenía más tiempo viviendo en San Sebastián, quiso sondear las probabilidades de éxito militar en los Estados Unidos, en el bando de Félix Díaz, por quien había volcado sus simpatías. Resulta difícil determinar en qué momento se trasladó al citado país, pero algo sucedió. A Mondragón dejó de interesarle participar en plan contrarrevolucionario alguno. Se abocó a realizar negocios relacionados con sus inventos militares, y la construcción de obras

70 Documentos históricos de la revolución mexicana xvı. Revolución y régimen constitucionalista. (1969, p. 84).

${ }^{71}$ Documentos históricos de la revolución mexicana xvı. (1969, p. 366).

72 Documentos históricos de la revolución mexicana XVI. (1969, p. 366).

73 SRE-AHD, leg. 270, f. 196. 
públicas, razón por la cual fue común que viajara a Europa, los Estados Unidos y Cuba. Una pieza más faltaba en el ajedrez. Todo indica que la estancia de José Refugio Velasco en España fue transitoria ya que para junio de 1915 vivía en Los Ángeles, California. ${ }^{74} \mathrm{Si}$ bien salió de México en la tercera semana de septiembre de 1914, ocurre que su estadía en el viejo mundo duró poco más de medio año. Se ignora la razón de su traslado al continente americano. Una hipótesis indica que, enterado del traslado de Victoriano Huerta a los Estados Unidos para recuperar el poder político en México, decidió secundarlo. Sólo que no existe evidencia en tal sentido. Es más, al parecer no se buscaron ni en España ni en los Estados Unidos.

Sin el apoyo de sus exsecretarios de Guerra y Marina, que ya estaban en los Estados Unidos, Huerta puso en marcha su movimiento. Casi de inmediato, las autoridades norteamericanas lo aprehendieron acusándolo de conspiración y violación a las leyes de neutralidad. Después de un juicio, y libertad bajo fianza, el 13 de enero de 1916 falleció, sin poder cruzar la frontera. ${ }^{75}$ La tan publicitada ayuda alemana, si es que existió, de nada sirvió. Al enterase de su muerte, ni Blanquet ni Mondragón mostraron señal alguna de consideración ni de duelo.

\section{El amargo exilio}

Ante el traslado de Huerta, Blanquet y Velasco a los Estados Unidos, más los frecuentes viajes de Mondragón a uno y otro lado del océano, en forma casi mecánica, otros mexicanos exiliados en la madre patria, siguieron sus pasos. Las razones: indiferencia de los españoles, nulas posibilidades de obtener un empleo, los estragos de la primera guerra mundial, y agotamiento de sus recursos. El ex secretario de Instrucción Pública, José María Lozano, soportó únicamente unos meses en el exilio, y en noviembre de 1914, partió hacia Nueva York junto con otras personas. ${ }^{76} \mathrm{El} 13$ de abril de 1915, Rafael Adalid, encargado del consulado en Madrid, le remitió a Jesús Acuña, secretario de Gobernación, la

\footnotetext{
74 Ramos (1960, p. 167).

75 Gamboa (1995, p. 314).

76 Juan Sánchez Azcona comenta a Miguel Covarrubias sobre la presencia de Huerta y los huertistas en España, Madrid, 10 de noviembre de 1914, en Illades (2001, p. 122).
}

ESTUDIOS DE HISTORIA MODERNA Y CONTEMPORÁNEA DE MÉXICO 55, enero-junio 2018, 159-194 DOI: http://dx.doi.org/10.22201/iih.24485004e.2018.55.64551 
petición de amnistía de Roberto A. Esteva Ruiz, que ansiaba regresar a México. Rafael Adalid abogó por el ex secretario de Relaciones Exteriores, afirmando haber recabado informes sobre su conducta. Todos ellos indicaban que durante su permanencia en la península, Esteva Ruiz había mostrado buena conducta, y dedicado al ejercicio de su profesión. Su alejamiento de la política era total.77 En su Diario, Federico Gamboa expresa que Díaz Mirón llegó a La Habana el 2 de noviembre de 1915. El dato confirma que el poeta estuvo en España poco más de un año. ${ }^{78}$ En la isla de Cuba el exilio le resultó más soportable que en España. Martín Luis Guzmán vivió en Madrid desde principios de 1915 hasta febrero de 1916, y luego se trasladó a los Estados Unidos. Se dice que Henríquez Ureña lo convenció de trasladarse a este país, y que incluso le consiguió un empleo en la Universidad de Minnesota, pero Guzmán prefirió Nueva York, por considerar que tenía mayores probabilidades de desarrollarse como escritor.

A Luis G. Pardo no le agradó mucho el exilio de Barcelona, y a mediados de julio de 1916 decidió trasladarse a México, con todos los riesgos que implicaba. Federico Gamboa reporta que el 4 de agosto llegó un barco a La Habana, con Luis G. Pardo a bordo, acompañado de su hermana María, ya viuda y una hijita. Con la ayuda de su hermano Rafael, planeaba encontrar un empleo para sobrevivir, pero apenas desembarcó en Veracruz, fue tomado preso. No se sabe la fecha de su liberación, pero el 18 de junio de 1917, el vapor María Cristina tocó costas cubanas rumbo a España, y en él viajaba Luis G. Pardo.79 Contra su voluntad, regresaba al exilio. El 3 de agosto de 1919, atracó un vapor en las costas de La Habana. Lo notable fue que en él viajaba Gumersindo Enríquez con destino a México. Atrás quedó su destierro en Barcelona. Sus hijos tramitaron su retorno a su patria. Viejo, triste, atemorizado, ya no podía más con el destierro. No obstante que el vapor tardaría uno o dos días en levantar anclas, apenas saludó a Federico Gamboa, para narrar sus amarguras y desgracias del destierro, regresó al barco, y ahí durmió. No quiso ver a nadie más. Su anhelo era estar en México con los suyos. ${ }^{80}$

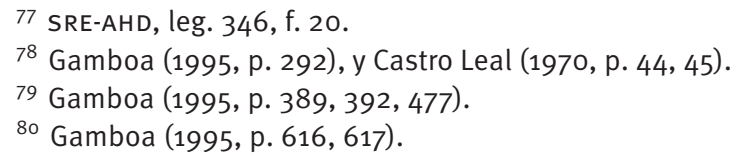


Hubo un caso extraño sobre el cual vale la pena referirse. Ocurre que el 1 de junio de 1916, el general Manuel M. Guasque, pasó por La Habana y visitó a Federico Gamboa. Procedía de Nueva Orleans, sin saberse si intervino en el montaje del movimiento contrarrevolucionario de Félix Díaz que estalló cuatro meses antes, en febrero para ser exactos. Gamboa lo describió como una persona alicaída y neurasténica. ${ }^{81}$ Después de ello, el general se embarcó rumbo a España, un país del cual huían los mexicanos. Porqué razón se refugió ahí. Posiblemente porque temía que en México Carranza lo atrapara y fusilara. En 1920, el obispo de San Luis Potosí, Ignacio Montes de Oca, vivía en calidad de residente en la Academia Eclesiástica de Nobles en Roma. Deseoso de regresar a su patria, se trasladó a España, y el 30 de julio de 1921 tomó un barco en Cádiz. El 12 de agosto desembarcó muy enfermo en Nueva York. Ocho días después, falleció, sin pisar tierra mexicana. ${ }^{82}$ Instalado en el poder en 1920, Adolfo de la Huerta brindó amplio apoyo al espectáculo taurino, y en especial, garantías para que Rodolfo Gaona retornara a México. ${ }^{83}$ El 18 de octubre de 1920, después de seis años de ausencia, Gaona piso suelo patrio. Para su fortuna, el público no lo había olvidado, y asimismo, nadie le reprochó su amistad con Huerta. Al año siguiente, intervino en los festejos del Centenario de la Independencia de México. En esta ocasión, y en otras más, lidió sendos bureles para el beneplácito de los generales Álvaro Obregón y Plutarco Elías Calles.

Ciertamente que una parte de los intelectuales y abogados, con sólida formación profesional, permanecieron en España. Rodolfo Reyes, quizás el expatriado más exitoso en el terreno profesional, convivió en San Sebastián con los ex ministros Adolfo de la Lama y Manuel Mondragón. Rodolfo definió al primero, como una persona inteligente y de nobles sentimientos; al segundo, como una persona simpática, pero agobiado por sus achaques y dolencias. ${ }^{84}$ Suerte similar corrió su hermano, Alfonso Reyes. Los sonorenses olvidaron su pasado al servicio de Huerta, y en 1920 fue designado Segundo Secretario de la Legación de México en España. La situación fue parecida para Fernando Pimentel y Fa-

\footnotetext{
${ }^{81}$ Gamboa (1995, p. 364).

82 Valverde Téllez (1949, p. 101).

83 Padilla (1987, p. 316, 319), y Gaona (1924, p. 175, 183, 187, 253-255).

84 Reyes (1930, p. 33).
} 
goaga, un hombre de talento para los negocios. Tanto en el negocio de la pavimentación de calles como de los bienes raíces, le permitieron vivir bien. Pudo haberse quedado en España, pero optó por regresar a México. En 1924 reanudó sus actividades financieras y en los bienes raíces. Se tienen noticias de que Pablo Macedo, uno de los “científicos", grupo comandado por José Yves Limantour, falleció en 1918 en Madrid. Impactado por los cambios registrados en México, y abatido por la desintegración de su familia, el 25 de junio de 1922, Manuel Mondragón falleció en San Sebastián. ${ }^{85}$ Para entonces, casi todos sus compatriotas habían dejado España. Sobre el resto de los exiliados en la "madre patria”, no existen datos sobre cuál fue su suerte, pero es posible que hayan regresado a México, con la derrota a cuestas. Atrás quedó un exilio amargo, y en ocasiones, hostil. La frialdad, la indiferencia con que fueron tratados en España, y los estragos de la primera guerra mundial, conspiraron en su contra. La pretendida hermandad, o vínculo con España, resultó nula.

Fuentes

Archivos

Secretaría de Relaciones Exteriores, Acervo Histórico Diplomático, Serie Embamex España (SRE-AHD)

Archivo Histórico Isidro Fabela

Hemerografía

Diario de la Marina

El Constitucionalista

El Imparcial

El Independiente

85 Tello Díaz (1993, p. 282). 
El País

El Pueblo

El Radical

Gil Blas

Heraldo de Cuba

La Atalaya

Revista de revistas

Bibliografía

BRUCE-NovoA (1987). “Estudio introductorio”, en M. L. Guzmán, La sombra del caudillo. México: Universidad Nacional Autónoma de México.

Caspistegui, F. J. (2014). "Neutralidad sobre el papel: España como campo de batalla en la primera guerra mundial". Memoria y civilización, v. 17, p. 159-172.

Castillo, R. (1980). “Estudio preliminar”, en F. A. de Icaza, Obras. t. I. México: Fondo de Cultura Económica.

Castro Leal, A. (1970). Díaz Mirón, Su vida y su obra. México: Porrúa.

De cómo vino Huerta y cómo se fue. (1975). México: El Caballito.

Documentos históricos de la revolución mexicana XVI. Revolución y régimen constitucionalista. (1969). Publicados bajo la dirección de J. E. de Fabela. v. 4 (1). México: Jus.

FlORES, O. (2001). El gobierno de su majestad Alfonso XIII ante la revolución mexicana. México: Senado de la República-Universidad de Monterrey.

GamboA, F. (1995). Mi diario vi (1912-1919). México: Consejo Nacional para la Cultura y las Artes.

GARCIADIEGO, J. y E. Kouri. (2010). Revolución y exilio en la historia de México: del amor del historiador a su patria adoptiva. Homenaje a Friedrich Katz. México: El Colegio de México.

GARCIADIEGo, J. (1998). “Alfonso Reyes cosmopolitismo diplomático y universalismo literario", en Escritores de la diplomacia mexicana. t. I. México: Secretaría de Relaciones Exteriores. 
GaOna, R. (1924). Mis veinte años de torero: el libro íntimo de Rodolfo Gaona. México: El Universal.

González Blanco, E. (1916). Carranza y la revolución de México. Madrid: Imprenta Helénica.

González Navarro, M. (1994). Los extranjeros en México y los mexicanos en el extranjero 1821-1970. v. III. México: El Colegio de México.

KATZ, F. (1982). La guerra secreta en México. 2 v. La revolución mexicana y la tormenta de la primera guerra mundial. México: ERA.

ILLADES, C. (1985). México y España durante la revolución mexicana. México: Secretaría de Relaciones Exteriores.

Jiménez AguiRre, G. (1998). “Amado Nervo. Una crónica de tres tiempos”, en Escritores de la diplomacia mexicana. t. I. México: Secretaría de Relaciones Exteriores.

Liceaga, L. (1958). Félix Díaz. México: Jus.

Mellado, G. (1914). Los crímenes del huertismo. México.

MEYER, L. (2001). El cactus y el olivo. Las relaciones de México y España en el siglo Xx. México: Océano.

Meyer, M. C. (1983). Huerta. Un retrato político. México: Domés.

PAdilla, G. E. (1987). El maestro Gaona. México: Compañía Editorial Impresora y Distribuidora, S. A.

Perea, H. (1996). La rueda del tiempo. México: Cal y Arena.

Portal, M. (1993). "El exilio madrileño de Martín Luis Guzmán”. Anales de literatura hispanoamericana 22, p. 257-266.

RAMíREZ RANCAÑo, M. (2002). La reacción mexicana y su exilio durante la revolución de 1910. México: Universidad Nacional Autónoma de México, Instituto de Investigaciones Sociales, Instituto de Investigaciones Históricas/Miguel Ángel Porrúa.

Ramos, M. S. (1960). Un soldado. Gral. José Refugio Velasco. México: Oasis.

Rausch Jr., G. (1962). "The exile and death of Victoriano Huerta”. The Hispanic American Historical Review 42 (2), p. 133-134.

Reyes, A. (1941). Pasado inmediato y otros ensayos. México: El Colegio de México. 
REYEs, R. (1930). De mi vida. Memorias políticas II, (México 1913-1914). Madrid: Espasa Calpe.

Rintelen, C. (1942). El oscuro invasor. México: Ediciones Quetzal.

RosENZWEIG, G. (2012). Los diplomáticos mexicanos durante la revolución: entre el desempleo y el exilio. Historia mexicana v. LXI (n. 4), p. 1461-1522.

SAX, A. (1916). Los mexicanos en el destierro. San Antonio, Texas.

TARACENA, A. (1991). La verdadera revolución mexicana (1912-1914). México: Porrúa.

Tello DíAz, C. (1993). El exilio. Un relato de familia. México: Cal y Arena.

Tuchman, B. W. (2010). El telegrama Zimmermann. Barcelona: Argos Vergara.

VAladÉs, J. (2007). La revolución y los revolucionarios. t. II. Parte Uno. La revolución constitucionalista. México: Instituto Nacional de Estudios Históricos de las Revoluciones de México.

VAlverde Téllez, E. (1949). Bio Bibliografía eclesiástica mexicana (1821-1943). t. II. México: Jus. 